\title{
ESSAY
}

\section{Hospice Care Today: Compassionate or McDonaldized? ${ }^{1}$}

\author{
Donalee Unal ${ }^{2}$
}

\begin{abstract}
[Article copies available for a fee from The Transformative Studies Institute. E-mail address: journal@transformativestudies.org Website: http://www.transformativestudies.org (C2011 by The Transformative Studies Institute. All rights reserved.]
\end{abstract}

It can be said that hospice is both old and new. The word hospice is from the Latin "hospes," meaning hospitality and has its roots in medieval times when it symbolized a place of shelter for tired or ill travelers from their long journey (The National Hospice and Palliative Care Organization, 2010). Today the term hospice has come to mean a philosophy of care that assists a person nearing the end of life and their loved ones, not only a place of respite (Doherty, 2009).

While hospice is relatively new to the United States, it has been in existence in the United Kingdom for over 75 years. The first hospice can be traced to Dublin, Ireland where Sister Mary Aikenhead, a member of the Irish Sisters of Charity, opened a home for the terminally ill in the mid-1800's. She called the home "hospice" because she viewed death as part of the eternal journey. Word spread of her work and she was invited to London by Cardinal Vaughan in 1900 where the sisters established St. Joseph's, one of the first hospices in England. Located in London's East End, today it is a 100-bed hospice facility. This facility has served as a model for other British hospices, most notably St. Christopher's Hospice. Dame Cicely Saunders established St. Christopher's hospice after

\footnotetext{
${ }^{1}$ This paper, was displayed in poster form at the Eastern Sociological Society annual meeting in February 2011 in Philadelphia, PA. and will be presented at a medical sociology roundtable at the annual meeting of the American Sociological Association in Las Vegas in August 2011.

${ }^{2}$ Donalee Unal is a graduate student in sociology with a concentration in medical sociology at the University of Maryland Baltimore County. Address correspondence to: Donalee Unal, 1171 Julianne Dr., Hummelstown, PA. 17036; e-mail: dwunal@comcast.net; Tel: (717)583-2163.
}

1937-0229 (C2011 Transformative Studies Institute 